\title{
Evaluation of probiotic treatment in a neonatal animal model
}

\begin{abstract}
The clinical use of probiotic agents such as enteral Lactobacillus to enhance intestinal defense against potential luminal pathogens has been tested in vivo; however, an understanding of the mechanisms responsible for the observed protection is lacking. The purpose of this study was to evaluate the effects of Lactobacillus on bacterial translocation (BT) in a neonatal animal model. Newborn New Zealand white rabbit pups were enterally fed a $10 \%$ Formulac solution inoculated with or without a $10^{8}$ suspension of ampicillin-resistant Escherichia coli $\mathrm{K} 1$ (E. coli K1A) and/or Lactobacillus casei GG (Lacto GG). Pups received either no bacteria $(\mathrm{n}=10)$, Lacto $\mathrm{GG}(\mathrm{n}=8)$, E. coli $\mathrm{K} 1 \mathrm{~A}(\mathrm{n}=26)$, or a combination of Lacto $\mathrm{GG}$ and $E$. coli $\mathrm{K} 1 \mathrm{~A}(\mathrm{n}=33)$. On day 3, representative tissue specimens from the mesenteric lymph nodes (MLN), spleen (SPL), and liver (LIV) were aseptically harvested in addition to a small-bowel (SB) sample that was rinsed to remove luminal contents. The specimens were then cultured in organism-specific media. Statistical analysis was by one-way ANOVA with $P$ values less than 0.05 considered significant. Neonatal rabbits receiving Lacto GG-supplemented formula exhibited a $25 \%$ decrease $(P<0.05)$ in small-bowel colonization by E. coli $\mathrm{K} 1 \mathrm{~A}$. In addition, Lacto $\mathrm{GG}$ decreased the frequency of extraintestinal BT by $46 \%(P<0.05), 61 \%$ $(P<0.05)$, and $23 \%$, respectively, in the MLN, SPL, and LIV. We have shown that enterally-administered Lacto GG decreases the frequency of E. coli K1A translocation in a neonatal rabbit model. These results may have significant implications for the treatment of BT and sepsis in the human neonate and provide a model for further studies.
\end{abstract}

D. J. Lee · R. A. Drongowski · A. G. Coran · C. M. Harmon (ه) University of Michigan Medical School,

Section of Pediatric Surgery,

F3970 Mott Children's Hospital,

Ann Arbor, MI 48109-0245,

USA
Key words Bacterial translocation · Probiotics . Neonate

\section{Introduction}

Disruption of the gut mucosal barrier (GMB) can occur as a result of various forms of stress and trauma, including infection, hypoxia, starvation, malnutrition, and postsurgical stress. Because the intestinal lumen houses large numbers of indigenous bacteria, during these times of barrier dysfunction opportunistic pathogens may penetrate the impaired GMB and disseminate to extraintestinal sites through a process called bacterial translocation (BT) [41]. It is believed that BT, defined as the passage of viable or nonviable enteric bacteria and their by-products across the intestinal barrier [6], is the cause of sepsis and various bacterial diseases in cases in which there is no other identifiable focus of infection [9]. BT is especially problematic in the hospital setting among the neonatal population, who are considered to be at increased risk of infection by enteric bacteria because of their compromised immune system and incompletely developed GMB. Findings confirming the correlation between age and frequency of BT support this concern [37]. Sepsis has been suspected to contribute to the onset of gastroenteritis, necrotizing enterocolitis, Crohn's disease, and other gastrointestinal (GI) disorders $[9,15,24]$.

Preserving the gut's protective ability against BT involves maintaining a physiologically normal intestinal microflora balance, gut and immunological function, and a healthy intestinal epithelium and mucosa [41]. Various treatment strategies have been proposed to help prevent the occurrence of BT, most of which involve a modification of one or more of these aspects. One such treatment involves the oral administration of probiotic bacteria, or probiotics, which are defined as viable bacteria that have a beneficial effect on the health of the host [30]. It has been suggested that these bacteria, when enterally administered, possess the ability to normalize 
altered GMB function. Probiotics are proposed to work through a number of different mechanisms including intestinal microflora modification, antagonistic activity against potentially pathogenic bacteria, stimulation of the immune system, and sustenance provision for the intestinal mucosa [4].

Clinical studies have suggested therapeutic effects of probiotic administration in infants and children $[15,19,23,24,29,34,38]$. Investigations utilizing animal models have also provided evidence for a probiotic capacity to stabilize the GMB $[1,10,17,25,39]$; however, adult animal models have been primarily utilized in these studies, with little focus on neonates. Wagner et al. assessed the growth and mortality of mice born to dams colonized with probiotic bacteria, but their results were inconclusive $[39,40]$. Due to the basic differences that exist between adult and neonatal gut physiology, it is important to establish a neonatal model by which the efficacy and mechanisms of probiotic treatment in an immature gut can be further studied.

In this study, we investigated the effects of lactobacillus probiotic treatment in a neonatal animal model. More specifically, we focused on the Lactobacillus casei GG (Lacto GG) strain and its enteric effect on BT of the exogenous pathogen Escherichia coli $\mathrm{K} 1$ (E. coli $\mathrm{K} 1)$ in neonatal rabbit pups. Through a method similar to one developed by Kazantsev et al. [22], the ampicillin-sensitive $E$. coli $\mathrm{K} 1$ strain was transformed with a plasmid encoding for ampicillin resistance, allowing for a convenient method to isolate and identify the specific pathogen of interest (E. coli K1A). The therapeutic efficacy of Lacto GG has been extensively studied, and its strong candidacy as a probiotic has been well established. We hypothesized that Lacto GG would act as an antagonist against the transformed $E$. coli $\mathrm{K} 1$ in this neonatal model, and that this would be evident in the inhibition of the colonization and BT by the pathogen.

\section{Materials and methods}

Formulac was obtained from the Unit for Laboratory Animal Medicine of the University of Michigan Medical Center. The pGEM-7Zf $(+)$ plasmid DNA (pGEM-7, $1 \mu \mathrm{g} / \mu \mathrm{l})$ was obtained from Promega (Madison, WI). E. coli K1 (ATCC 23503) and Lacto GG (ATCC 53103) were obtained from the American Type Culture Collection (Manassas, VA). Formamide and LB broth base were obtained from Gibco BRL (Grand Island, NY). The Select Agar used in combination with the LB broth base to make LB agar was obtained from Sigma (St. Louis, MO). Rogosa SL broth and agar were obtained from VWR Scientific Products (Detroit, MI). 5-bromo-4-chloro-3-indolyl- $\beta$-D-galactopyranoside (X-Gal) was obtained from Fisher Scientific (Pittsburgh, PA). Ampicillin was obtained from the University of Michigan Medical Center (Ann Arbor, MI). A stock solution of X-Gal dissolved in formamide was prepared $(40 \mathrm{mg} / \mathrm{ml})$ and $1 \mathrm{ml}$ of this solution was supplemented into $11 \mathrm{LB}$ agar medium so that the final concentration of X-Gal in the LB agar plates was $40 \mu \mathrm{g} / \mathrm{ml}$.

On the day of delivery, newborn New Zealand white rabbits pups were separated from their mothers, placed in an Isolette infant incubator maintained at $28{ }^{\circ} \mathrm{C}$, and given orogastric gavage feedings of $2 \mathrm{ml} \mathrm{10 \%} \mathrm{Formulac} \mathrm{twice} \mathrm{daily} \mathrm{via} \mathrm{a} 5$ Fr premature infant feeding tube. The guidelines stated in NIH Principles of Laboratory Animal Care (NIH publication No. 85-23, revised 1985) were followed.

$E$. coli $\mathrm{K} 1$ were transformed with a non-transferable, 3,000 base-pair pGEM-7 plasmid encoding for ampicillin resistance. Non-transformed E. coli K1 displayed ampicillin sensitivity. Transformation was performed using the calcium chloride/heat shock method developed by Cohen et al. [8]. Briefly, E. coli $\mathrm{K} 1$ were rinsed twice with ice-cold $0.1 \mathrm{M} \mathrm{CaCl} 2$ and kept on ice in order to make them competent for transformation. The pGEM-7 plasmid was then added to the competent bacteria, placed on ice for $30 \mathrm{~min}$, heat shocked $\left(42^{\circ} \mathrm{C}\right)$ for $45 \mathrm{~s}$ to allow pGEM-7 transformation, and then placed back on ice for $2 \mathrm{~min}$. The bacteria were then incubated in SOC medium for a $1 \mathrm{~h}$ recovery period, plated on LB agar plates supplemented with ampicillin $(100 \mu \mathrm{g} / \mathrm{ml})$ and X-Gal $(40 \mu \mathrm{g} / \mathrm{ml})$, and incubated for $24 \mathrm{~h}$ at $37^{\circ} \mathrm{C}$. The $\mathrm{X}-\mathrm{Gal}$ in the LB agar serves as a substrate for the lacZ alpha-peptide, also encoded by the pGEM-7 plasmid. Through the expression of this gene, successfully transformed E. coli $\mathrm{K} 1$ appeared as blue colonies on the X-Gal-supplemented LB agar plates. Several blue colonies of transformed $E$. coli $\mathrm{K} 1$ were randomly selected using a flame-sterilized inoculating loop and used to start stock cultures that were grown in LB broth supplemented with ampicillin $(100 \mu \mathrm{g} / \mathrm{ml})$ at $37^{\circ} \mathrm{C}$. Transformed ampicillin-resistant $E$ coli $\mathrm{K} 1$ (E. coli $\mathrm{K} 1 \mathrm{~A})$ served as our pathogen in the current model.

According to American Type Culture Collection (ATCC), a 5\% $\mathrm{CO}_{2}$ environment is the ideal culturing condition for Lacto $\mathrm{GG}$, but we found that growth in the Rogosa broth was not inhibited by aerobic conditions. Stock cultures of Lacto GG were grown aerobically in a lactobacillus-selective Rogosa broth at $37^{\circ} \mathrm{C}$ and served as the probiotic.

Seventy-seven rabbit pups were randomly separated into four groups based on their respective feeding regimens: (1) controls $(\mathrm{n}=10) ; \quad(2) \quad$ LGG $(\mathrm{n}=8) ; \quad(3) \quad \mathrm{K} 1 \mathrm{~A} \quad(\mathrm{n}=26) ;$ and (4) $\mathrm{LGG}+\mathrm{K} 1 \mathrm{~A}(\mathrm{n}=33)$. For the LGG, K1A, and LGG $+\mathrm{K} 1 \mathrm{~A}$ groups, the $10 \%$ Formulac solution was inoculated with a suspension of Lacto GG and/or a suspension of E. coli K1A depending on the group being fed (Table 1). Feedings were administered twice daily for 2 days. Each pup in these groups received $10^{8}$ Lacto GG and/or $10^{8}$ E. coli K1A per feeding. Rabbit pups were returned to the infant incubator $\left(28^{\circ} \mathrm{C}\right)$ between feedings, and were not allowed access to additional food or water.

On day 3 , the pups were anesthetized with a subcutaneous dose of acepromazine $(1 \mathrm{mg} / \mathrm{kg})$ followed by an intramuscular dose of ketamine $\mathrm{HCl}(50 \mathrm{mg} / \mathrm{kg})$. In preparation for tissue extraction, the anterior abdominal wall was prepped with betadine solution and a sterile laparotomy was performed. Representative tissue specimens were aseptically harvested from the mesenteric lymph nodes (MLN), spleen (SPL), liver (LIV), and jejunum of the small-bowel (SB), in this sequence, using a different set of sterile instruments for each tissue to minimize the possibility of bacterial contamination between samples. The small-bowel lumen was aseptically irrigated with $2 \mathrm{ml}$ sterile saline prior to culturing in order to clear the luminal contents.
Table 1 Inoculation of bacteria into feeding solutions

\begin{tabular}{|c|c|c|c|c|}
\hline Group & Feeding 1 & Feeding 2 & Feeding 3 & Feeding 4 \\
\hline $\begin{array}{l}1 \text { Control } \\
2 \text { LGG } \\
3 \mathrm{~K} 1 \mathrm{~A} \\
4 \mathrm{LGG}+\mathrm{K} 1 \mathrm{~A}\end{array}$ & $\begin{array}{l}\text { No bacteria } \\
\text { Lactobacillus GG } \\
\text { No bacteria } \\
\text { Lactobacillus GG }\end{array}$ & $\begin{array}{l}\text { No bacteria } \\
\text { Lactobacillus GG } \\
\text { No bacteria } \\
\text { Lactobacillus GG }\end{array}$ & $\begin{array}{l}\text { No bacteria } \\
\text { Lactobacillus } \mathrm{GG} \\
\text { E. coli } \mathrm{K} 1 \mathrm{~A} \\
\text { Lactobacillus } \mathrm{GG} \\
+ \text { E. coli } \mathrm{K} 1 \mathrm{~A}\end{array}$ & $\begin{array}{l}\text { No bacteria } \\
\text { Lactobacillus } \mathrm{GG} \\
\text { E. coli } \mathrm{K} 1 \mathrm{~A} \\
\text { Lactobacillus } \mathrm{GG} \\
+ \text { E. coli } \mathrm{K} 1 \mathrm{~A}\end{array}$ \\
\hline
\end{tabular}


Tissue specimens were divided into two samples and aerobically incubated for $48 \mathrm{~h}$ at $37{ }^{\circ} \mathrm{C}$ in $3 \mathrm{ml} \mathrm{LB}$ broth supplemented with ampicillin $(100 \mu \mathrm{g} / \mathrm{ml})$ and $3 \mathrm{ml}$ Rogosa broth. Due to the small size of the MLN, the specimen was homogenized in $0.5 \mathrm{ml}$ sterile saline and then $0.2 \mathrm{ml}$ homogenate was inoculated into both selective broths. After $48 \mathrm{~h}$, broth aliquot samples were aseptically streaked onto selective agar plates and incubated for $24 \mathrm{~h}$ at $37^{\circ} \mathrm{C}$. Unlike the Rogosa broth, the Rogosa agar plates were incubated in an anaerobic chamber due to the poor ability of Lacto GG to grow on these plates in an aerobic environment. Detection of viable $E$. coli K1A was determined by the growth of blue streaks or blue colonies on the LB agar plates and detection of viable Lacto GG by any white, opaque streaks or colonies on the Rogosa agar plates. Data were recorded as either presence or absence of either bacterium in each tissue sample. Final frequencies of E. coli K1A and Lacto GG growth were calculated for the MLN, SPL, LIV, and SB data. The presence of either bacterium in the MLN, SPL, or LIV was interpreted as BT of that bacterium to those sites. The presence of either bacterium in the SB was interpreted as colonization by that bacterium.

Representative samples of SB from all groups were stored in a $37 \%$ formaldehyde buffer solution and later subjected to hematoxylin and eosin (H\&E) staining and light-microscopy analysis by a pathologist. The data were analyzed using one-way analysis of variance with Sheffe's post-hoc testing for multiple comparisons between groups. $P$ values less than 0.05 were considered significant.

\section{Results}

Although newborns are initially germ-free, the rabbit pups used in this study were not kept in a germ-free environment, and so establishing the selectivity of our model and methodology for the pathogen and probiotic was critical. No growth of $E$. coli $\mathrm{K} 1 \mathrm{~A}$ was detected in the MLN, SPL, LIV, and SB in the control or LGG group. Since both of these groups were not administered E. coli $\mathrm{K} 1 \mathrm{~A}$, they served as negative controls with results establishing that the pathogen was not indigenous to the neonatal rabbit, and confirming the selectivity of the model for the pathogen. This enabled us to conclude with confidence that any $E$. coli $\mathrm{K} 1 \mathrm{~A}$ present in the tissues originated from the exogenous supply in the feedings, which allowed us to focus specifically on colonization and BT by this bacterium.

Rogosa broth and agar are only selective for Lactobacillus sp., not specifically for Lacto GG. However, no growth of any Lactobacillus sp. was detected in the MLN, SPL, LIV, and SB of the control and K1A groups. Neither group was administered Lacto GG, indicating that there were no lactobacilli indigenous to the neonatal rabbit, and hence, the selectivity of the model for the probiotic was confirmed. Observation of colonization and BT Lacto GG through detection of its presence in the tissue specimens could, therefore, also be done with confidence.

There was a $25 \%$ decrease in the frequency of $E$. coli K1A colonization of the SB $(0.85$ to $0.64, P<0.05)$ between the K1A and LGG + K1A groups (Fig. 1). The frequency of E. coli K1A translocation to the MLN decreased by $46 \%(0.50$ to $0.37, P<0.05)$ between the $\mathrm{K} 1 \mathrm{~A}$ and $\mathrm{LGG}+\mathrm{K} 1 \mathrm{~A}$ groups. BT to the SPL decreased by $61 \%(0.31$ to $0.12, P<0.05)$ between the $\mathrm{K} 1 \mathrm{~A}$ and $\mathrm{LGG}+\mathrm{K} 1 \mathrm{~A}$ groups. The LIV exhibited a

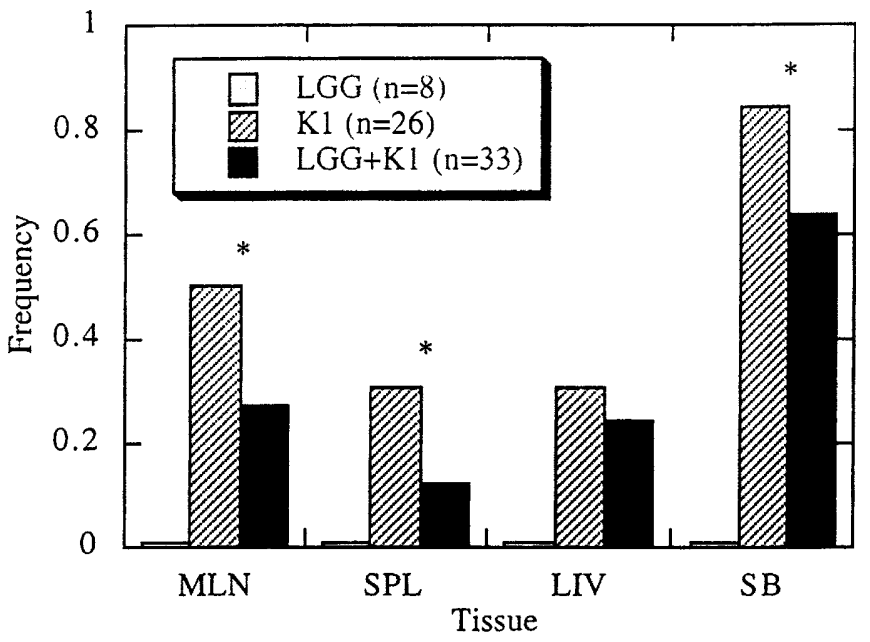

Fig. 1 Frequency of E. coli K1A presence calculated for mesenteric lymph nodes $(M L N)$, spleen $(S P L)$, liver $(L I V)$, and small bowel $(S B)$. LGG pups displayed no presence of bacteria, while LGG + K1A pups exhibited decreased frequency in all tissues compared to K1A pups

$* P<0.05$

$23 \%$ decrease in BT frequency between these two groups (0.31 to 0.24$)$, but the decrease was not statistically significant.

The frequency of Lacto GG colonization of the SB decreased by $56 \%$ comparing the LGG and LGG + K1A groups ( 0.88 to $0.39, P<0.05$, Fig. 2$)$. No significant differences were detected in the frequency of Lacto GG BT to the extraintestinal sites between the LGG and LGG + K1A groups. Therefore, Lacto GG translocation to the MLN, SPL, and LIV did not seem to be affected by the presence of $E$. coli K1A, but was detected at low frequencies in both the LGG and LGG + K1A groups. In the LGG group, none of the

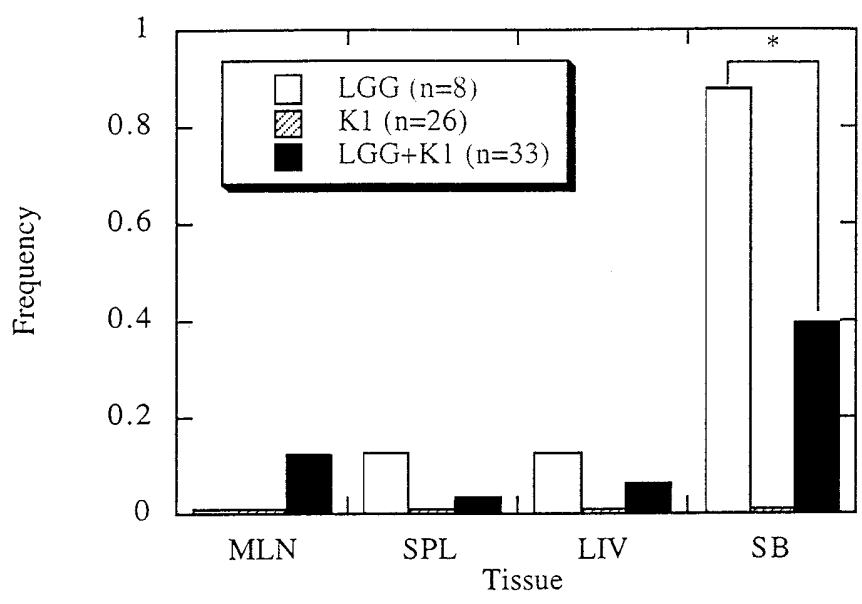

Fig. 2 Frequency of Lactobacillus GG presence calculated for mesenteric lymph nodes $(M L N)$, spleen $(S P L)$, liver $(L I V)$, and small bowel $(S B)$. K1A pups displayed no bacteria, LGG + K1A pups exhibited decreased SB frequency compared to K1A pups, both groups exhibited low frequencies in the MLN, SPL, and LIV $* P<0.05$ 
pups showed signs of probiotic translocation to the MLN, while 1 of the 8 pups exhibited BT to the SPL and LIV (0.13). In the LGG $+\mathrm{K} 1 \mathrm{~A}$ groups, the frequency of Lacto GG BT to the MLN, SPL, and LIV was detected at $0.12,0.03$, and 0.06 , respectively. Histologic examination of the SB (H\&E) did not show any dissimilarities between the groups observable through light microscopy. Mucosal damage was not detected in the SB of any of the groups (data not shown).

Rabbit pups in any one group did not show clinical signs of being more healthy or ill than pups of any other group. A low mortality of $7 \%$ was observed across all groups. No group exhibited significantly higher mortality than the others (data not shown). Mortality seemed attributable to congenital factors of poor health or injuries suffered during gavage feedings rather than to pathogenesis by enteric bacteria. Rabbit pups who either died before tissue harvest or displayed bleeding of the esophageal lining due to excessive trauma during gavage feedings $(2 \%)$, as evidenced by the presence of regurgitated blood in the mouth, were excluded from the data.

\section{Discussion}

It is believed that the GI tract of the neonate is physiologically incomplete in its development at the time of birth compared to that of the adult. Evidence for this immaturity was indicated by a study performed in our laboratory demonstrating that the neonatal rabbit was prone to a higher incidence of BT than the adult rabbit [37]. Neonates display a propensity toward immature immune function [16,34], microfloral ecology [5], gut function (motility, gastric acid secretion, proteolytic activity) $[18,33,35]$, mucosa and mucosal gel layer development $[13,28,31]$, and intestinal epithelial development [31]. Since the normal neonate exhibits several of the factors that have been postulated to promote BT in the adult [9], it is not unreasonable to speculate that probiotics may provide similar benefits for the neonate.

This assertion has been suggested by various clinical studies involving infants and children with GI disorders $[15,19,23,24,29,36,38]$. Animal studies have also been performed in an attempt to identify proficient probiotic strains and ascertain the effects and mechanisms of probiotic treatment $[1,10,17,25,39]$. Most of these studies, however, utilized adult models with little attention given to probiotic treatment in a neonatal model. While studying the protective capacities of different probiotic strains in immunodeficient adult mice, Wagner et al. also assessed the effect on mice born to dams colonized with probiotic bacteria [39]. Specifically, they examined the growth and mortality of the mice at 4 and 8 to 12 weeks after delivery, but their results were inconclusive and no analysis of the probiotic effects on the GMB was performed. It seems that, due to the basic physiological differences in the GI tract of neonates and adults, a neonatal model must be established in which probiotics can be further studied. The results obtained in the current study support the candidacy of the proposed neonatal rabbit model.

We evaluated the ability of the probiotic Lacto GG to inhibit BT and dissemination of $E$. coli $\mathrm{K} 1 \mathrm{~A}$ in a neonatal rabbit model. The human Lacto GG strain has exhibited characteristics that make it a good candidate for probiotic treatment: Lacto GG has been shown to survive in the GI tract of different animal models and humans $[14,17,20]$, adhere to the human Caco-2 intestinal cell line [11], produce an antimicrobial substance [32], and has generally had a good safety record [29]. Use of this strain in clinical and laboratory studies has produced results verifying its probiotic ability. The $E$. coli K1 strain that was transformed with the pGEM-7 plasmid was isolated from human infants and has been known to be highly virulent in newborns, causing meningitis and bacteremia [12]. Transforming the $E$. coli $\mathrm{K} 1$ with the plasmid enabled us to easily isolate and identify the pathogen from the tissue samples. Further identification of $E$. coli K1A can be performed through plasmid DNA analysis, as was done in a previous study performed in our laboratory [26].

The finding of principal interest in this study was that Lacto GG inhibited the colonization of E. coli K1A and its translocation to extraintestinal sites. In previous studies, the incidences of BT and dissemination were used as indicators of the integrity of the GMB. Thus, our results imply that Lacto GG was able to stabilize the immature GMB, establishing its efficacy as a probiotic in the neonatal rabbit model. Histologic analysis of the small bowel did not show any mucosal damage inflicted by $E$. coli $\mathrm{K} 1 \mathrm{~A}$, indicating that this was not a mechanism responsible for the translocation process in this animal. This is further supported by the observation that Lacto GG BT did not significantly increase in the $\mathrm{LGG}+\mathrm{K} 1 \mathrm{~A}$ group. If the $E$. coli $\mathrm{K} 1 \mathrm{~A}$ were to cause mucosal damage, then one would expect to also see an increase in Lacto GG translocation. It seems that prevention of mucosal damage was not a mechanism by which Lacto GG inhibited BT of the pathogen in this model.

Colonization of the germ-free newborn GI tract normally does not begin until after exposure to the extrauterine environment. This immature microfloral ecology provides an opportunity for overgrowth of any single strain of bacteria in the gut, since it is able to proliferate without competition [5]. Hence, introduction of $E$. coli $\mathrm{K} 1 \mathrm{~A}$ or Lacto GG into the GI milieu would most likely lead to small-bowel colonization by these bacteria, as indicated by the high colonization frequency occurring in pups monoassociated with either $E$. coli K1A or Lacto GG in our data. However, the frequencies of colonization by $E$. coli $\mathrm{K} 1 \mathrm{~A}$ and Lacto $\mathrm{GG}$ declined in pups associated with both bacteria, possibly indicating luminal competition between the two bacteria and an established balance in the microfloral ecology.

As relatively nonpathogenic bacteria, probiotics have been shown to provide the resistance necessary to suppress the overgrowth of potentially pathogenic bacteria 
in adult animals, presumably through competition for nutrients and adhesion sites along the GI lining $[1,17,25,39]$. It has also been suggested that probiotics impede proliferation of potential pathogens through stimulation of the immune response and lymphocyte development $[5,7,34,39]$ and through the production of antimicrobial compounds and other inhibitory molecules $[2,27,32]$, although it is questionable whether these substances are produced in vivo.

Lactobacillus sp. are considered relatively nonpathogenic bacteria in the general human population. In the current study, we observed a low frequency of BT by Lacto GG, less than 0.13 , to extraintestinal sites. Although there was no apparent clinical distress among the pups infected with Lacto GG, evidence of any translocation of putative probiotic is a cause for concern, especially in immunodeficient hosts such as the neonate. In a study assessing the pathogenesis of probiotic bacteria in congenitally immunodeficient mice, Wagner et al. concluded that the probiotic species they tested were innocuous for adults but were associated with mortality and decreased growth rates in pups born to dams colonized with the bacteria [40]. These results, in conjunction with our own, suggest that further studies evaluating the safety of probiotic treatment in the neonate should be initiated.

Our results provide some evidence of the beneficial effects of probiotic administration in neonates and propose a neonatal animal model by which this treatment can be further studied. The Lacto GG strain used in this study appeared to display effects in the neonatal rabbit characteristic of an ideal probiotic; however, in previous studies, different strains have exhibited different probiotic capacities. The most promising probiotic strains that have emerged in clinical studies have been primarily lactic-acid strains, including Lactobacillus casei, Lactobacillus acidophilus, Lactobacillus reuteri, and Bifidobacterium bifidum [4]. The efficacy of these and other probiotic strains should be further tested in a neonatal model in order to identify those most suitable for probiotic therapy in newborns and infants. In addition, the use of prebiotics, substrates that are effective in modifying the microflora, can be evaluated as an indirect therapeutic approach capable of inducing the proliferation of indigenous probiotic bacteria within the GI tract $[3,21]$. Future studies utilizing the nenonatal model should provide insight into the mechanisms by which probiotics exert their beneficial effects.

\section{References}

1. Adawi D, Kasravi FB, Molin G, Jeppsson B (1997) Effect of Lactobacillus supplementation with and without arginine on liver damage and bacterial translocation in an acute liver injury model in the rat. Hepatology 25: 642-647

2. Axelsson LT, Chung TC, Dobrogosz WJ, Lindgren E (1989) Production of a broad spectrum antimicrobial substance by Lactobacillus reuteri. Microb Ecol Health Dis 2: 131-136

3. Bengmark S (1998) Immunonutrition: role of biosurfactants, fiber, and probiotic bacteria. Nutrition 14: 585-594
4. Bengmark S, Gianotti L (1996) Nutritional support to prevent and treat multiple organ failure. World J Surg 20: 474-481

5. Berg RD (1980) Inhibition of Escherichia coli translocation from the gastrointestinal tract by normal cecal flora in gnotobiotic or antibiotic-decontaminated mice. Infect Immun 29: 1073-1081

6. Berg RD, Garlington AW (1979) Translocation of certain indigenous bacteria from the gastrointestinal tract to the mesenteric lymph nodes and other organs in a gnotobiotic mouse model. Infect Immun 23: 403-411

7. Crabbé PA, Bazin H, Eyssen H, Heremans JF (1968) The normal microbial flora as a major stimulus for proliferation of plasma cells synthesizing IgA in the gut. Int Arch Allergy Appl Immunol 34: 362-375

8. Cohen SN, Chang ACY, Hsu L (1973) Nonchromosomal antibiotic resistance in bacteria: genetic transformation of Escherichia coli by R-factor DNA. Proc Natl Acad Sci USA 70: 3240

9. Deitch EA (1994) Role of bacterial translocation in necrotizing enterocolitis. Acta Paediatr Suppl 396: 33-36

10. Dong M, Chang T, Gorbach SL (1987) Effects of feeding Lactobacillus GG on lethal irradiation in mice. Diagn Microbiol Infect Dis 7: 1-7

11. Elo S, Saxelin M, Saxelin S (1991) Attachment of Lactobacillus casei strain GG to human colon carcinoma cell line Caco-2: comparison with other dairy strains. Lett Appl Microbiol 13: 154-156

12. Glode MP, Sutton A, Moxon ER, Robbins JB (1977) Pathogenesis of neonatal Escherichia coli meningitis: induction of bacteremia and meningitis in infant rats fed $E$. coli $\mathrm{K} 1$. Infect Immun 16: 75-80

13. Go LL, Ford HR, Watkins SC, Healey PJ, Albanese CT, Donhalek A, Simmons RL, Rowe MI (1994) Quantitative and morphologic analysis of bacterial translocation in neonates. Arch Surg 129: 1184-1190

14. Goldin BR, Gorbach SL, Saxelin M, Barakat S, Gualtieri L, Salminen S (1992) Survival of Lactobacillus species (strain GG) in human gastrointestinal tract. Dig Dis Sci 37: 121-128

15. Guarino A, Canani RB, Spagnuolo MI, Albano F, Benedetto LD (1997) Oral bacterial therapy reduces the duration of symptoms and of viral excretion in children with mild diarrhea. J Pediatr Gastroenterol Nutr 25: 516-519

16. Hanson LA, Ahlstedt S, Andersson B, Carlson B, Fallstrom SP, Mellander L, Purras O, Soderstrom T, Eden CS (1985) Protective factors in milk and the development of the immune system. Pediatrics 75: 172-176

17. Hudault S, Lievin V, Bernet-Camard MF, Servin AL (1997) Antagonistic activity exerted in vitro and in vivo by Lactobacillus casei (strain GG) against Salmonella typhimurium C5 infection. Appl Environ Microbiol 63: 513-518

18. Hyman PE, Clarke DD, Everett SL, Sonne B, Stewart D, Harada T, Walsh JH, Taylor IL (1985) Gastric acid secretory function in preterm infants. J Pediatr 106: 467-471

19. Isolauri E, Juntunen M, Rautanen T, Sillanaukee P, Doivula T (1991) A human Lactobacillus casei strain (Lactobacillus casei strain GG) promotes recovery from acute diarrhea in children. Pediatrics 88: 90-97

20. Isolauri E, Majamaa H, Arvola T, Rantala I, Virtanen E, Arvilommi H (1993) Lactobacillus casei strain GG reverses increased intestinal permeability induced by cow milk in suckling rats. Gastroenterology 105: 1643-1650

21. Kasper H (1998) Protection against gastrointestinal diseases present facts and future developments. Int $\mathbf{J}$ Food Microbiol 41: $127-131$

22. Kazantsev GB, Hecht DW, Rao R, Fedorak IJ, Gattuso P, Thompson K, Djuricin G, Prinz RA (1994) Plasmid labeling confirms bacterial translocation in pancreatitis. Am J Surg 167: 201-207

23. Majamaa H, Isolauri E, Saxelin M, Vesikari T (1995) Lactic acid bacteria in the treatment of acute rotovirus gastroenteritis. J Pediatr Gastroenterol Nutr 20: 333-338

24. Malin M, Suomalainen H, Saxelin M, Isolauri E (1996) Promotion of IgA immune response in patients with Crohn's dis- 
ease by oral bacteriotherapy with Lactobacillus GG. Ann Nutr Metab 40: $137-145$

25. Mao Y, Nobaek S, Kasravi B, Adawi D, Stenram U, Molin G, Jeppsson B (1996) The effect of Lactobacillus strains and oat fiber on methotrexate-induced enterocolitis in rats. Gastroenterology 111: 334-344

26. Moy J, Lee D, Harmon CM, Drongowski RA, Coran AG (1999) Confirmation of the gastrointestinal origin of translocated bacteria in a neonatal model. J Surg Res: (in press)

27. Müller E, Radler F (1993) Caseicin, a bacteriocin from Lactobacillus casei. Folia Microbiol 38: 441-446

28. Okuyama H, Urao M, Lee D, Abe A, Drongowski RA, Harmon CM, Coran AG (1998) Changes, with age, in the phospholipid content of the intestinal mucus layer of the newborn rabbit. J Pediatr Surg 33: 35-38

29. Raza S, Graham SM, Allen SJ, Sultana S, Cuevas L, Hart CA (1995) Lactobacillus GG promotes recovery from acute nonbloody diarrhea in Pakistan. Pediatr Infect Dis J 14: 107-111

30. Salminen S, Isolauri E, Salminen E (1996) Clinical uses of probiotics for stabilizing the gut mucosal barrier: successful strain and future challenges. Antonie Van Leeuwenhoek 70: 347-358

31. Sheard NF, Walker A (1998) The role of breast milk in the development of the gastrointestinal tract. Nutr Rev 46: 1-8

32. Silva M, Jacobus NV, Deneke C, Gorbach SL (1987) Antimicrobial substance from a human Lactobacillus strain. Antimicrob Agents Chemother 31: 1231-1233

33. Udall JN, Bloch KJ, Vachino G, Feldmann P, Walker WA (1984) Development of gastrointestinal mucosa barrier. IV. The effect of inhibition of proteolysis on the uptake of mac- romolecules by the intestine of the newborn rabbit before and after weaning. Biol Neonate 45: 289-295

34. Urao M, Teitelbaum DH, Drongowski RA, Coran AG (1996) The association of gut-associated lymphoid tissue and bacterial translocation in the newborn rabbit. J Pediatr Surg 31: 14821487

35. Urao M, Okuyama H, Drongowski RA, Teitelbaum DH, Coran AG (1997) Intestinal permeability to small- and largemolecular-weight substances in the newborn rabbit. J Pediatr Surg 32: 1424-1428

36. Urao M, Fujimoto T, Lane GJ, Seo G, Miyano T (1999) Does probiotics administration decrease serum endotoxin levels in infants? J Pediatr Surg 34: 273-276

37. Van Camp JM, Tomaselli V, Drongowski RA, Coran AG (1995) Bacterial translocation in the newborn rabbit: effect of age on frequency of translocation. Pediatr Surg Int 10: 134 137

38. Vanderhoof JA, Young RJ, Murray N, Kaufman SS (1998) Treatment strategies for small bowel bacterial overgrowth in short bowel syndrome. J Pediatr Gastroenterol Nutr 27: 155160

39. Wagner RD, Pierson C, Warner T, Dohnalek M, Farmer J, Roberts L, Hilty M, Balish E (1997) Biotherapeutic effects of probiotic bacteria on candidiasis in immunodeficient mice. Infect Immun 65: 4165-4172

40. Wagner RD, Warner T, Roberts L, Farmer J, Balish E (1997) Colonization of congenitally immunodeficient mice with probiotic bacteria. Infect Immun 65: 3345-3351

41. Wells CL (1996) Colonization and translocation of intestinal bacterial flora. Transplant Proc 28: 2653-2656 